\title{
Pandangan Pendidikan Islam Kotemporer Terhadap Pemberdayaan Masyarakat
}

\author{
Supardi Dwimaputra \\ UIN Imam Bonjol Padang \\ Email: dwimaputrasupardi@yahoo.com
}

\begin{abstract}
Abstrak
Fokus utama artikel ini adalah mengkaji wacana pendidikan Islam dari perspektif filsafat pemberdayaan. Sejalan dengan pandangan ini, ia mengusulkan kerangka konseptual baru untuk pemberdayaan sebagai pengganti pandangan tradisional, yang mempertimbangkan pemberdayaan dalam hal pembangunan infrastruktur atau pergeseran kekuasaan dari yang kuat ke yang tidak berdaya. Kami menyarankan bahwa pemberdayaan harus dilihat sebagai proses sosial yang membantu orang mendapatkan kendali atas hidup mereka dengan memungkinkan mereka untuk bertindak atas isu-isu penting bagi mereka. Dilihat dari sudut ini, pendidikan yang berupaya memberdayakan orang harus menjadi proses yang memberikan kebebasan dan sumber daya mendasar untuk memahami dunia dan memberikan kemampuan untuk mengubah dunia itu. Wacana pendidikan Islam kontemporer dievaluasi atas dasar ini untuk menentukan sejauh mana pendidik Islam terlibat dengan gagasan pemberdayaan yang diusulkan dalam artikel ini.
\end{abstract}

Kata Kunci: Pendidikan Islam, Kotemporer, Pemberdayaan.

\begin{abstract}
Examining Islamic education from the standpoint of empowerment is the primary goal of this article. Instead of the traditional notion of empowerment as infrastructure development or a movement from the powerful to the powerless, he provides a new conceptual framework for activation. Empowerment, in our opinion, should be viewed as a societal process that allows people to take charge of their own lives and make decisions about things that matter to them personally. An educational process that aims to empower people must, from this perspective, provide the freedom and resources essential for comprehending the world and giving one's self authority to alter it. This article's concepts are based on the assumption that the discourse of Islamic education may be used to gauge how much involvement Islamic educators have with them.
\end{abstract}

Keywords: Islamic Education, Contemporary, Empowerment.

\section{A. PENDAHULUAN}

Perhatian utama dari hampir semua teori sosial adalah bagaimana memberdayakan orang, meskipun istilah itu sendiri dibiarkan tidak terdefinisi atau didefinisikan secara samar. Hebatnya, karena sebagian besar sistem politik yang ada telah gagal mengaktualisasikan martabat manusia, kebebasan, dan keadilan sosial yang sejati selama dekade terakhir, konsep pemberdayaan telah muncul sebagai fokus penelitian sosial (Hadi, 2010). Kebanyakan ahli teori sosial percaya bahwa orang harus diberdayakan. Pemberdayaan masyarakat bertujuan untuk membantu individu atau kelompok masyarakat berpindah dari satu tingkat kualitas hidup ke tingkat yang lain, sehingga meningkatkan kualitas hidup mereka. Karena itu, istilah 
"pemberdayaan" telah mencakup berbagai mata pelajaran, termasuk pendidikan, ekonomi, politik, dan kesulitan sosial budaya (Istan, 2017).

Tapi ada satu masalah yatitu bagaimana seseorang mendefinisikan arti dan tujuan pemberdayaan? Banyak yang menggunakan istilah ini untuk menunjukkan ide yang berbeda. Misalnya, sebagian besar pemerintah modern berasumsi bahwa adalah mungkin untuk memberdayakan kelompok tertentu, terutama orang-orang yang terpinggirkan dalam masyarakat, dengan memberi mereka dukungan ekonomi atau menerapkan perubahan infrastruktur yang menguntungkan mereka (Kesuma, 2017). Yang lain berpikir bahwa ini mungkin ketika manusia menikmati kebebasan untuk melakukan apa yang mereka inginkan atau membebaskan diri dari ikatan dan kewajiban sosial-keagamaan. Definisi-definisi ini memang mengandung beberapa nuansa makna, tetapi mereka gagal untuk membahas banyak dimensi lain yang lebih mendasar dari istilah tersebut, seperti yang akan dibahas di bawah ini.

Pendidikan Islam telah diakui secara luas sebagai komponen kunci pemberdayaan masyarakatdalam konteks ini. Pendidikan adalah proses meningkatkan dan melengkapi secara sistematis semua potensi moral, intelektual, dan fisik seseorang, baik untuk kepentingan individu maupun untuk kepentingan masyarakat secara keseluruhan (Roqib, 2009). Sistem Pendidikan Nasional Indonesia memasukkan pendidikan Islam sebagai salah satu subsistemnya. Tidak akan ada diskusi yang berarti tentang masa depan sistem pendidikan Indonesia tanpa juga membahas nasib penduduk Muslim Indonesia. Pendidikan Islam memiliki sejarah panjang di Indonesia, mendukung pembangunan bangsa baik sebelum maupun setelah Indonesia merdeka.

Sudah sejak lama pemerintah dan para pakar pendidikan berupaya meningkatkan kualitas pendidikan, termasuk pendidikan Islam. Tapi hasilnya belum sebaik yang mereka bisa. Ada perbedaan besar antara cita-cita dan kenyataan sekarang. Peningkatan mutu pendidikan secara utuh masih belum mungkin dilakukan. Keluaran peserta didik, yang kebetulan bukan yang terbaik bagi pendidikan Islam bagi peserta didik, orang tua, dan masyarakat lainnya. Pendidikan Islam di Indonesia saat ini dianggap hanya mampu memenuhi aspek normatif dan belum mampu memenuhi apa yang diharapkan. Muslim di negara ini tidak akan bisa menggunakan pendidikan Islam untuk membantu mereka menjadi lebih kuat. Ini adalah masalah utama (Tabrani, 2014).

Kami melihat pemberdayaan sebagai proses sosial yang membantu orang mendapatkan kendali atas hidup mereka dengan diizinkan untuk bertindak atas isu-isu yang mereka anggap penting. Pada bagian awal artikel kami mengusulkan pentingnya pemahaman baru tentang pemberdayaan dalam konteks pendidikan. Untuk melakukan ini, kami fokus untuk menjelaskan perbedaan pemahaman tentang pemberdayaan dan implikasinya terhadap pendidikan. Analisis ini juga bermaksud untuk menunjukkan asumsi yang mendasari konsep baru pemberdayaan dengan menyoroti keadaan yang menuntut pengenalan pemahaman yang berbeda tentang pemberdayaan dalam konteks pendidikan. Analisis kekuatan dan kelemahan wacana pendidikan Islam kontemporer dari perspektif filosofi pemberdayaan. Ini menekankan perubahan positif yang harus diperkenalkan ke dalam wacana pendidikan Islam untuk memasukkan berbagai dimensi yang mendasari pemberdayaan.

\section{B. METODE}

Studi ini menggunakan paradigma interpretif dan pendekatan kualitatif untuk memperoleh data teknis melalui tinjauan pustaka. Hal ini dicapai dengan membaca, meneliti, mempelajari, memahami, menganalisis, dan mengumpulkan informasi dari berbagai literatur dan peraturan yang berkaitan dengan masalah penelitian (Sugiyono, 2011). Metode analisis yang digunakan adalah deskriptif-kualitatif, artinya data dideskripsikan terlebih dahulu kemudian dianalisis untuk mendapatkan suatu kesimpulan. Analisis data meliputi langkahlangkah sebagai berikut: (1) Meneliti semua data yang dikumpulkan dari berbagai sumber, baik 
primer maupun sekunder; (2) Mengklasifikasikan semua data ke dalam unit-unit masalah sesuai dengan rumusan masalah; (3) Menganalisis unsur-unsur argumen yang digunakan untuk membahas masalah; dan (4) Menarik kesimpulan dari hasil analisis terhadap permasalahan yang dibahas.

\section{HASIL DAN PEMBAHASAN}

Beberapa studi tentang pendidikan secara eksplisit menjelaskan mengapa pemberdayaan harus dijadikan isu pendidikan. Selain itu, berbagai dokumen dan karya penelitian telah membuktikan bahwa sebagian besar lembaga pendidikan telah menjadi instrumen untuk ketidakberdayaan dengan membuat siswa pasif dan patuh pada sistem sosial yang ada. Melihat fakta-fakta tersebut, banyak upaya telah dilakukan di bidang sosial politik selama satu dekade terakhir untuk membawa konsep pemberdayaan ke dalam bidang pendidikan. Sebelum menentukan apa arti khusus dari pemberdayaan dalam bidang pendidikan, beberapa pandangan yang dibahas secara umum perlu digarisbawahi.

Salah satu pendekatan yang menonjol adalah memandang pemberdayaan sebagai sesuatu yang berkaitan dengan pembangunan dan kemajuan. Pandangan ini telah menyebabkan kecenderungan umum untuk melihat pemberdayaan sebagai cara untuk meningkatkan layanan dan infrastruktur kesejahteraan melalui mediasi institusi sosial. Mempertimbangkan pembangunan dan kemajuan ekonomi sebagai kriteria utama untuk memastikan keberhasilan dan kekuasaan, pendekatan ini menunjukkan bahwa pemberdayaan dimungkinkan setelah orang menikmati kemajuan ekonomi dan kemajuan teknologi. Oleh karena itu, mereka yang menganut perspektif ini tidak akan dapat melihat pemberdayaan sebagai sesuatu yang lebih dari sekadar menyalurkan lebih banyak dana untuk memperkenalkan perubahan infrastruktur di semua jenis struktur sosial. Meningkatnya jumlah sekolah, puskesmas, jalan raya, dan jalan raya atau pendirian gedung dan lembaga baru akan dinilai sebagai indikator pemberdayaan yang signifikan (Chaniago, 2015).

Ketika pemberdayaan divisualisasikan dari perspektif pembangunan-ekonomi, itu akan lebih memperhatikan perubahan kuantitatif yang akan dimiliki oleh alokasi dan distribusi sumber daya dan kekayaan. Saat ini, badan-badan internasional seperti Dana Moneter Internasional (IMF) dan Bank Dunia mengembangkan perspektif ini di antara kelas penguasa di dunia berkembang sehingga proyek infrastruktur yang mereka rekomendasikan dapat diperkenalkan sebagai "sarana" untuk diberdayakan. Perspektif ini telah membuat negaranegara Dunia Ketiga bergantung pada negara lain, terutama dunia korporat, karena mereka percaya bahwa cara pembangunan ini akan segera membuat mereka kuat.

Menurut pandangan ini, jika seseorang dari kelas ekonomi yang lebih rendah memperoleh posisi yang luar biasa atau profesi penting dalam hierarki sosial, ini akan dianggap sebagai penanda pemberdayaan yang signifikan. Alasan utama untuk ini adalah bahwa orang tersebut telah melampaui batasan yang ditetapkan oleh masyarakat karena efisiensi, keterampilan, dan kemampuan pribadinya. Mereka yang berpandangan demikian mengungkapkan kecenderungan untuk memperkenalkan program-program yang berhubungan dengan pelatihan kepemimpinan, lokakarya manajemen, dan kegiatan serupa dalam kurikulum pendidikan. Mereka percaya bahwa penekanan dalam usaha ini akan meningkatkan prestasi individu atau komunitas. Perspektif ini, yang dapat diidentifikasi sebagai "perspektif profesional," juga mengasumsikan bahwa tenaga kerja yang lebih kompeten adalah tenaga kerja yang lebih berdaya dan lebih produktif. Akibatnya, isu-isu seperti efisiensi diri, manajemen kerja, kepercayaan diri, dan manajemen kekuasaan telah menjadi fokus diskusi (Aminah, 2016).

Dilihat dari perspektif pergeseran kekuasaan, kekuasaan dianggap sebagai sesuatu yang dipinjamkan atau ditransfer, bukan diciptakan. Sekali lagi, pandangan ini menganjurkan bahwa yang tidak berdaya dapat menjadi kuat baik dengan bergantung pada kebaikan yang kuat atau 
dengan merebut kekuasaan dari mereka. Upaya politik sebagian besar negara demokrasi modern untuk memperkuat kelompok-kelompok yang terpinggirkan berakar dari asumsi ini. Oleh karena itu, konsep pembagian kekuasaan sekarang dianggap sebagai nilai demokrasi yang sangat dihargai, dan sejumlah besar negara modern cenderung mengatakan bahwa mereka telah menghilangkan marginalisasi dengan memberikan bagian yang tertindas dalam proses pemerintahan. Memperkenalkan reservasi atau sistem kuota dalam layanan pemerintah yang sangat terhormat, mengalokasikan kuota di konstituen parlementer dan dewan legislatif lokal, kebijakan tindakan afirmatif untuk mendukung kelompok yang lebih lemah, dan tindakan serupa dipandang sebagai cara praktis untuk mencapai pemberdayaan.

Sejauh menyangkut praktik pendidikan Islam, filosofi pemberdayaan ini memiliki banyak kesamaan dengan gagasan Islam tentang khalifah dan keadilan sosial, karena istilah khusus ini menggarisbawahi otonomi manusia, kebebasan memilih, dan kesetaraan. Dengan ini, Islam dengan tegas menetapkan bahwa setiap individu memiliki kekuasaan dan otonominya sendiri. Karena Allah menganggap semua manusia secara individu bertanggung jawab atas tindakan mereka sendiri dan telah memberi mereka kebebasan untuk memilih, merekalah yang menentukan bagaimana mereka akan bertindak: "Kalau begitu siapa yang mau, biarlah dia percaya; dan siapa yang menghendaki, biarkan dia kafir. Adalah tanggung jawab setiap orang untuk menggunakan semua sumber daya yang disediakan oleh Allah untuk membuat tindakannya lebih bermanfaat, dengan pemahaman bahwa kebaikan dari tindakan ini akan dievaluasi pada Hari Pembalasan (Najahah, 2016).

Untuk lebih spesifiknya, tidak seorang pun diberi hak untuk menegaskan kekuasaan atau otoritasnya atas orang lain. Manusia tidak boleh dipaksa untuk melakukan sesuatu yang bertentangan dengan keinginan mereka, karena mereka harus menikmati hak dasar penentuan nasib sendiri. Oleh karena itu, setiap orang berhak untuk memutuskan hidup mereka dengan bertindak atas isu-isu yang mereka anggap penting. Ini hanya satu langkah menuju pemberdayaan. Karena Allah telah memberi kita kemampuan untuk membedakan yang benar dan yang salah, membiarkan orang menggunakan kemampuan itu menjadi prinsip inti pemberdayaan. Satu-satunya hal yang harus dilakukan adalah menanamkan dalam diri individu rasa nilai mereka sendiri sebagai manusia dan kapasitas untuk menangani masalah kehidupan (Ratnasari, 2016).

Sayangnya, upaya Muslim untuk membawa asumsi yang mendasari pemberdayaan ke dalam wacana pendidikan Islam agak jarang. Ini bukan karena mereka tidak penting, tetapi karena para cendekiawan Muslim (dan juga sebagian besar Muslim) tidak terlalu tertarik dengan hal ini. Ini menjelaskan kelangkaan studi tentang masalah ini (Hikam, 2000). Namun, beberapa penulis Muslim telah menyatakan keprihatinan yang mendalam atas isu-isu tersebut. Misalnya, Yedullah Kazmi mencatat bahwa hubungan yang jelas antara pendidik pedagogi kritis dan mereka yang tertarik pada pendidikan Islam adalah komitmen bersama mereka terhadap keadilan sosial dan minat yang bersamaan dalam memberdayakan siswa untuk menundukkan dunia pada ujian kritis agar lebih adil. Ia membahas berbagai konsep filosofis pendidikan Islam dan pentingnya pemberdayaan dalam konteks islam. Konsep-konsepnya, seperti murabbi, 'abd, dan "alam kebenaran" dapat dianggap sebagai salah satu upaya pertama untuk membawa beberapa elemen pemberdayaan ke dalam wacana filosofis Islam (Kasmar dkk, 2019).

Salah satu penegasan mereka adalah bahwa lembaga pendidikan Islam kontemporer telah gagal menghubungkan teori dan prinsip yang diajarkan di kelas dengan dunia tempat siswa tinggal. Alih-alih memikirkan konten yang diajarkan di sekolah dan integrasi kurikulum, pendidik Muslim harus memikirkan kembali tujuan pendidikan. Mereka juga menegaskan bahwa ketergantungan yang luas pada sistem standar pendidikan (misalnya, kurikulum standar, pengujian, dan administrasi) telah menjadi hambatan untuk meningkatkan keadilan sosial karena secara tidak sadar mereproduksi nilai-nilai dominan. Mengingat realitas ini, model 
kontemporer modern sekolah pada dasarnya anti-pembelajaran di alam dan, yang secara inheren tidak efektif dan tidak efisien pada usia berapa pun, gagal untuk memelihara potensi manusia untuk apa pun selain pekerjaan.

Fazlur Rahman (1988), seorang sarjana terkemuka di Universitas Chicago, mencoba untuk menegaskan pentingnya memanfaatkan pendidikan untuk mengubah dunia. Meskipun perhatian utamanya bukan untuk membawa pemberdayaan ke dalam pendidikan Islam, ia menyatakan bahwa umat Islam harus mengambil pengetahuan sebagai sarana untuk membawa perubahan ke dunia sosial. Baginya, "Al-Qur'an adalah buku yang berorientasi pada tindakan par excellence" dan "Islam mengajarkan dan mengarahkan manusia untuk mengubah hal-hal di dunia, di dunia luar." Oleh karena itu ia percaya bahwa umat Islam berkewajiban untuk terlibat dengan dunia dalam perintah untuk mengubahnya. Menggabungkan gagasan perubahan sosial dengan pengetahuan, ia menegaskan bahwa "pengetahuan dalam Islam ada untuk memungkinkan kita bertindak, untuk mengubah peristiwa terkini di dunia.

Suhailah Hussien (2007) juga telah melakukan studi mendalam tentang krisis pendidikan Islam untuk mengembangkan pedagogi kritis Islam, yang memandang proyek Islamisasi pendidikan sebagai respon. Dia membahas kemungkinan merekonstruksi pedagogi kritis barat dari perspektif Islam dan karena itu secara kritis menganalisis filsafat pendidikan Islam dengan mendefinisikan kembali konsep intinya. Namun tujuannya bukan untuk menciptakan filosofi pendidikan Islam yang memasukkan filosofi pemberdayaan; melainkan untuk mengislamkan pedagogi kritis barat dengan mempertimbangkan penerapan metode pengajaran pedagogis kritis dalam konteks Malaysia.

Selain studi-studi tersebut, tidak ada studi signifikan lainnya yang menekankan konsep pemberdayaan dalam konteks pendidikan Islam. Sebagian besar penulis Muslim bahkan belum melakukan upaya yang signifikan untuk menekankan perlunya bergabung dengan mereka yang mengkritisi sistem pendidikan kontemporer. Sebagai konsekuensi dari pengabaian ini, para cendekiawan Muslim belum memberikan kontribusi positif terhadap proses rekonstruksi pendidikan Islam dengan mengartikulasikan proyek pendidikan di mana Islam dikembalikan ke tempat yang seharusnya: pusat pemikiran dan tindakan masyarakat.

Gagasan utama para cendekiawan revivalis adalah bahwa "Islam adalah jalan hidup yang tidak memisahkan spiritualitas dari kehidupan duniawi." Menurut mereka, Islam memiliki kemampuan untuk diterjemahkan ke dalam konteks tertentu sehingga dapat didekodekan dalam konteks modern. Pandangan mereka telah meyakinkan umat Islam tentang pentingnya aksi sosial dalam upaya berkelanjutan untuk membawa masyarakat mereka sejalan dengan prinsip-prinsip Islam. Persepsi umum tentang Islam sebagai agama yang semata-mata ritualistik telah digantikan dengan persepsi yang memberikan Islam peran sentral dalam proses pembangunan bangsa. Namun, terlepas dari visi beberapa cendekiawan Muslim tentang Islam sebagai realitas dan kekuatan sosiopolitik, tidak ada upaya yang berhasil dilakukan untuk menghubungkan pendidikan dengan pemberdayaan dan emansipasi.

Ketika para pemikir pendidikan Muslim kemudian seperti Isma'il al-Faruqi (dibunuh pada 1986) dan Syed Muhammad al Naquib al-Attas mencoba mengembangkan filosofi pendidikan Islam yang menarik yang dikenal sebagai proyek Islamisasi Pengetahuan (IOK), jelas bahwa mereka mengakui signifikansi sosiopolitik Islam dan mengambil sikap tegas menentang proses sekularisasi. Upaya mengatasi krisis agama dalam modernitas ini dapat dipandang sebagai salah satu tanggapan intelektual Muslim kontemporer yang paling kredibel terhadap modernitas. Semua ulama yang mendukungnya secara eksplisit menyatakan bahwa kebingungan di kalangan umat Islam adalah akibat dari sistem pendidikan ganda, yang satu sekuler dan modern, dan yang lain religius dan tradisional. Oleh karena itu, para penganut proyek menegaskan bahwa perlunya "munculnya dari kelompok ketiga yang mengenal tradisi mereka sendiri tetapi bersedia untuk memperoleh kebijaksanaan apa pun yang dapat ditawarkan oleh peradaban modern (Maulana, 2017). 
Mereka yang memperkenalkan proyek IOK mendefinisikan Islamisasi pengetahuan sebagai pemberian kepentingan yang sama antara pengetahuan agama dan duniawi untuk mengatasi dikotomi antara pengetahuan agama dan ilmu-ilmu modern. Dalam pengertian ini, proses ini dapat dilihat sebagai integrasi yang mengingatkan kembali pada para sarjana sebelumnya yang mencoba mempertahankan pendekatan moderat antara tradisionalisme dan modernisme. Namun jika menyangkut aspek sosial agama, gagasan Islamisasi sebagai integrasi secara teoritis menolak persepsi agama sebagai apolitis. Dengan demikian proyek IOK dapat dianggap sebagai sintesis modernisme moderat (yaitu, upaya untuk mendamaikan pengetahuan modern dengan ajaran Islam tanpa melanggar batas-batas iman) dan revivalisme Islam (yaitu, upaya untuk mengembalikan dimensi sosial politik Islam).

Namun dalam arti praktis, meskipun Islamisasi berkaitan dengan masalah pendidikan sekuler dan pentingnya mengintegrasikan pengetahuan tradisional dan modern, mayoritas lembaga pendidikan Muslim tidak menunjukkan minat yang serius dalam menghubungkan proses pendidikan dengan realitas sosial politik kontemporer. Dengan kata lain, mereka yang berusaha merancang dan kemudian menerapkan sistem pendidikan yang direformasi belum menyadari pentingnya dan hubungan pemberdayaan dan emansipasi dengan konteks pendidikan. Harus dinyatakan bahwa proyek IOK dapat menginspirasi umat Islam di seluruh dunia dan bahkan mungkin beberapa pemimpin mereka. Bahkan, beberapa dari yang terakhir telah menyatakan komitmen mereka untuk proyek tersebut dengan mendukung lembaga. Pendirian universitas Islam internasional di Malaysia dan Pakistan dapat dianggap sebagai indikasi yang jelas dari dukungan positif tersebut. Proyek ini setidaknya telah meyakinkan para intelektual Muslim tentang bahaya sekularisme dan tantangan dualisme.

Karena baik neokolonialisme maupun imperialisme tidak memungkinkan orang untuk berimajinasi sendiri, implikasi sosiokulturalnya sangat jelas: (1) mereka menggagalkan semua kemungkinan dan potensi manusia sebagai khalifah, dengan demikian mengingkari hak asasi manusianya dan kebebasan memilih; (2) melemahkan orang dari berpartisipasi aktif di dunia; dan (3) mempertanyakan gagasan kesetaraan dan keadilan sosial dengan menyangkal jutaan orang (sekarang disebut "terpinggirkan") bahkan kesempatan untuk hidup. Selain itu, dengan menjadikan semua lembaga pendidikan sebagai usaha bisnis, mereka merusak nilai pendidikan dengan mereduksinya menjadi sesuatu yang menjamin posisi ekonomi dalam struktur kekuasaan masyarakat. Karena agenda neokolonial modal keuangan global menghalangi keadilan dan kesetaraan, membuat siswa sadar akan realitas sosial politik dunia kontemporer harus menjadi isu pendidikan (Ahsan dkk, 2013).

Bagi umat Islam, ini berarti bahwa wacana pendidikan Islam harus membahas masalah ekonomi pasar dan modal keuangan global karena membahas masalah sekularisme dan dualisme. Dengan kata lain, upaya desekularisasi umat harus dikembangkan secara konkrit dengan mengekspos kepentingan korporasi raksasa dan keuangan global terkait pendidikan. Mereka yang membela pendidikan Islam berkewajiban untuk mengambil sikap tegas terhadap imperialisme sosial politik yang didorong oleh ekonomi pasar dan perusahaan multinasional. Dalam pengertian itu, pendidik Islam harus menjadi proaktif dan membuat siswa mereka sadar akan sifat berbahaya dari kebijakan pendidikan neokolonial yang ada dan sedang berlangsung yang telah diperkenalkan oleh kekuatan eksternal ini ke tengah-tengah mereka. Sayangnya, tidak ada cendekiawan Muslim yang terlibat dalam upaya serius untuk mengungkap fakta bahwa hegemoni modal keuangan global membuat pendidikan Islam menjadi sesuatu yang mustahil untuk dicapai. Oleh karena itu, hampir tidak ada di antara mereka yang mau repotrepot membahas isu globalisasi dan ekonomi pasar secara mendetail dengan mengacu pada dampak negatifnya terhadap pendidikan. Bahkan lebih sedikit yang berani meminta negaranegara Muslim untuk menghindari proyek-proyek yang didukung oleh lembaga keuangan global seperti IMF dan Bank Dunia. 
Meskipun sebagian besar cendekiawan Muslim telah banyak menulis tentang dampak berbahaya sekularisme terhadap pendidikan Islam, tidak cukup banyak yang dilakukan untuk menunjukkan bahwa pendidikan Islam harus berbeda dari proyek pendidikan berorientasi bisnis yang ada. Berkaitan dengan pendidikan, keberhasilan IOK terletak pada upaya kerasnya untuk menyadarkan masyarakat akan kelemahan sekularisme dan sistem pendidikan dualistik. Sepanjang diskusi, sekularisme dianggap sebagai filosofi yang menolak peran sakral di ranah publik. Selain itu, dampaknya telah diproyeksikan dalam kaitannya dengan perannya dalam menyebarkan perasaan anti-agama di kalangan anak muda terpelajar. Meskipun aspek-aspek ini harus dibahas, umat Islam perlu menyadari bahwa sekularisme pada prinsipnya dapat ditemukan dalam ideologi dan filosofi. Seseorang tidak dapat menghilangkan konsekuensi berbahayanya hanya dengan menghilangkan sistem pendidikan dualistik atau membangun kurikulum terpadu. Sebaliknya, upaya yang disengaja harus dilakukan untuk menunjukkan kondisi sosial politik dan ideologi yang membentuk cara hidup sekuler. Isu kapitalisme dan ekonomi pasar harus ditangani dari perspektif ini.

Sayangnya, mereka yang mendukung pendidikan Islam tidak mengakui pemberdayaan sebagai isu pendidikan yang penting, mungkin karena pendidik Islam telah gagal melihat pendidikan dari perspektif sosiologis. Akibatnya, gagasan tentang apa itu pendidikan Islam telah dipersempit secara signifikan dan biasanya dianggap sebagai sesuatu yang hanya berurusan dengan hal-hal abstrak dari spiritualitas, sebagai lawan dari masalah manusia yang konkret. Hal ini menyebabkan kecenderungan yang meluas dalam masyarakat Muslim untuk menolak dengan keras segala upaya untuk menghubungkan proses pendidikan dengan realitas sosial politik kontemporer. Selain itu, karena sebagian besar pendidik Muslim lebih peduli dengan terminologi, definisi, dan praktik pendidikan arus utama, mereka telah mencoba mengembangkan terminologi Islam yang sesuai tanpa secara kritis merefleksikan konsistensi mereka dengan pedagogi Islam. Mereka lebih mementingkan bagaimana menerjemahkan sebuah kata atau frase Al-Qur'an yang diberikan sehingga sesuai dengan terminologi pendidikan modern daripada membuat saran yang konkrit dan substansial mengenai pendidikan Islam. Oleh karena itu, dimensi sosiopolitik, yang sangat mendasar bagi konsep semua jenis pendidikan, tidak dibahas secara memadai.

Karena kurangnya perhatian terhadap faktor-faktor sosial politik yang mengontrol proses pendidikan, upaya untuk menanamkan nilai-nilai Islam ke dalam kegiatan pendidikan akhirnya terbatas pada penyesuaian struktural yang hanya berusaha mengganti beberapa terminologi pendidikan barat dengan kata-kata Arab. Misalnya, cendekiawan Muslim telah memberikan lebih banyak waktu untuk menentukan bagaimana konsep manusia yang baik berbeda dari gagasan barat tentang warga negara yang baik. Lebih lanjut, ada yang menyatakan bahwa pendidikan Islam harus berusaha menciptakan manusia yang baik, bukan warga negara yang baik. Sepanjang diskusi ini, konsep khalīfah telah digunakan untuk menunjukkan "manusia yang baik" atau "manusia yang lurus secara moral." Tetapi bagaimana perbedaan antara warga negara yang baik dan manusia yang baik menandai perbedaan yang signifikan dalam praktik pendidikan Islam? Perhatian seharusnya adalah apakah isu-isu konkret yang disorot di sini tercermin dalam terminologi yang digunakan.

Sebagian besar reformis Islam yang menganalisis skenario pendidikan dunia Muslim kolonial dan pascakolonial berpendapat bahwa masalah utama dengan lembaga pendidikan Islam tradisional adalah ketidakmampuannya untuk melatih siswa untuk terlibat di dunia. Alasan untuk ini adalah karena kebanyakan madāris tradisional mengabaikan peran Muslim di dunia ini dan dengan demikian lembaga-lembaga tradisional sama sekali mengabaikan pengetahuan duniawi. Tetapi bahkan setelah keberhasilan implementasi kurikulum terpadu di berbagai negara, masalah seperti itu terus ada. Jelas, upaya Muslim di bidang pendidikan telah meningkatkan kondisi material masyarakat dengan memberi mereka kesempatan yang cukup untuk mempelajari pengetahuan dan sains modern. Upaya untuk mengintegrasikan 
pengetahuan modern dengan studi Islam tradisional telah memudahkan siswa untuk mengakses pengetahuan, terutama dalam pekerjaan profesional yang sangat dihormati.

Dalam pengertian ini, kegiatan pendidikan Islam, termasuk proyek IOK, telah membantu umat Islam dalam keselamatan pribadi mereka. Tetapi tanggung jawab utama umat Islam adalah untuk mencapai keselamatan sosial, sebuah konsep yang didefinisikan sebagai meningkatkan kehidupan masyarakat dengan menciptakan situasi sosial di mana setiap orang akan diperlakukan sama. Ratusan ayat Al-Qur'an mendorong umat Islam untuk bekerja secara aktif untuk membersihkan dunia dari kemiskinan, ketidaksetaraan, penindasan, ketidakadilan, dan lain sebagainya. Tak seorang pun dapat menemukan surga pribadi dengan mengabaikan masalah orang-orang yang tinggal di sekitarnya. Jadi Muslim harus hidup di dunia sedemikian rupa sehingga mereka mengenali orang-orangnya. Dalam konteks ini, pendidikan Islam harus menciptakan suasana yang mendorong peserta didik untuk terlibat dalam dunia manusia. Ini adalah persyaratan vital pemberdayaan.

\section{KESIMPULAN}

Pendidikan Islam harus menciptakan lingkungan yang mendorong dan membimbing siswa untuk memahami dunia ini untuk mengubahnya. Untuk lebih spesifik, itu harus memberdayakan siswa dengan memperlengkapi mereka untuk melakukan sesuatu yang lebih baik di dunia ini. Muslim kontemporer dan telah memainkan peran utama dalam menghilangkan persepsi sempit tentang agama dengan membuat hubungan antara spiritualitas dan dunia, mereka yang menjamin pendidikan Islam belum terlalu memperhatikan filosofi Islam. Pemberdayaan. Jadi dalam hal pemberdayaan ummat dengan menghilangkan kepasifan tradisional para anggotanya dan menjadikan mereka perancang kehidupan mereka sendiri, para pendidik Islam masih memiliki banyak pekerjaan yang harus dilakukan. Selain itu, untuk mengubah umat Islam menjadi aktor dinamis yang secara aktif menangani masalah sosial manusia yang konkret seperti eksploitasi ekonomi, ketimpangan sosial, dan neokolonialisme, wacana pendidikan Islam masih harus dimodifikasi dengan memasukkan beberapa wacana filosofis utama pendidikan kontemporer.

\section{REFERENSI}

Ahsan, M. A., Shahed, A. K. M., \& Ahmad, A. (2013). Islamization of Knowledge: An Agenda for Muslim Intellectuals. Global Journal of Management and Business Research.

Aminah, S. (2016). Kuasa Negara pada Ranah Politik Lokal. Prenada Media.

Chaniago, S. A. (2015). Pemberdayaan Zakat dalam Mengentaskan Kemiskinan. Jurnal Hukum Islam, 47-56.

Hadi, A. P. (2010). Konsep Pemberdayaan, Partisipasi Dan Kelembagaan Dalam Pembangunan. Yayasan Agribisnis/Pusat Pengembangan Masyarakat Agrikarya (PPMA).

Hikam, M. A. S. (2000). Islam, Demokratisasi, dan Pemberdayaan Civil Society. Erlangga.

Hussien, S. (2007). Critical pedagogy, Islamisation of knowledge and Muslim education. Intellectual Discourse, 15(1).

Istan, M. (2017). Pengentasan Kemiskinan Melalui Pemberdayaan Ekonomi Umat Menurut Persfektif Islam. Al-Falah: Journal of Islamic Economics, 2(1), 81-99.

Kasmar, I. F., Amnda, V., Mutathahirin, M., Maulida, A., Sari, W. W., Putra, S., ... \& Engkizar, E. (2019). The Concepts of Mudarris, Mu'allim, Murabbi, Mursyid, Muaddib in Islamic Education. Khalifa: Journal of Islamic Education, 3(2), 107-125.

Kesuma, G. C. (2017). Pemberdayaan Pendidikan Islam dalam Upaya Mengantisipasi Kehidupan Masyarakat Modern. Al-Tadzkiyyah, 8(1), 177531. 
Maulana, M. F. (2017). IOK The Islamization of Knowledge (IOK) An Experience of International Islamic University Malaysia An Experience of International Islamic University Malaysia. JOURNAL OF CREATIVE WRITING| ISSN 2410-6259, 3(02), 23-41.

Najahah, N. (2016). Pemberdayaan Masyarakat Dalam Perspektif Pendidikan Islam. JURNAL LENTERA: Kajian Keagamaan, Keilmuan dan Teknologi, 15(2), 134-147.

Rahman, F. (1988). Islamization of knowledge: A response. American Journal of Islamic Social Sciences, 5(1), 3-11.

Ratnasari, D. (2016). Pemberdayaan Perempuan dalam Pendidikan Pesantren. 'Anil Islam: Jurnal Kebudayaan dan Ilmu Keislaman, 9(1), 122-147.

Roqib, M. (2009). Ilmu Pendidikan Islam; Pengembangan Pendidikan Integratif di Sekolah, Keluarga dan Masyarakat. LKIS Pelangi Aksara.

Sabarudin, M. (2015). Pola dan Kebijakan Pendidikan Islam Masa Awal dan Sebelum Kemerdekaan. TARBIYA: Jurnal Ilmu Pendidikan Islam, 1(1), 139-174.

Sugiyono, P. (2011). Metodologi Penelitian Kuantitatif Kualitatif dan R\&D. Bandung: Alpabeta.

Tabrani, Z. A. (2014). Isu-Isu Kritis dalam Pendidikan Islam Perspektif Pedagogik Kritis. Jurnal Ilmiah Islam Futura, 13(2), 250-270. 